\title{
HEALTH-RELATED QUALITY OF LIFE IN UKRAINIAN YOUNG CHILDREN: SELF-REPORTS AND PROXY REPORTS
}

\author{
Iuliia PAVLOVA ${ }^{*}$, Oksana FEDECHKO ${ }^{1}$, Ivanna BODNAR ${ }^{1}$ \\ ${ }^{1}$ State University of Physical Culture, Lviv, Ukraine \\ *Corresponding author: pavlova.j.o@gmail.com
}

DOI: $10.35189 /$ iphm.icpesk.2019.28

\begin{abstract}
An analysis of children's quality of life allows answering a number of questions related to better understanding the problems in the child development. The purpose of the study was to analyse the differences in the physical and psychosocial components of the life quality of the child of preschool age by the responses of children and parents. The survey was attended by 57 children (passport age - 5 years) and their parents. The Pediatric Quality of Life Inventory (PedsQL) was used to assess the quality of life. The results were evaluated according to 4 scales - Physical Functioning (PF), Emotional Functioning (EF), Social Functioning $(S F)$, Kindergarten Functioning $(K F)$. Nonparametric analysis was used to compare the responses of parents and children. For most scales, the quality of life indicators exceeded 75 points ( $P F-78.7$ points, EF - 82.3 points, SF - 76.1 points). The score recorded by parents for the quality of life of the child was lower and differed in the scales $P F$ (by 10.9 points, $p<0.001$ ), EF (by 12.7 points, $p<0.001$,) KF (by 9.2 points, $p=0.02$ ). The quality of life of Ukrainian preschool children is in a high range, but is lower in comparison with healthy respondents of the same age group from other countries. Critical for the low-value scales identified problems with peers. Parents give a more critical assessment of various aspects of the functioning of the child and are a source of additional information about the quality of life of the child.
\end{abstract}

Keywords: health-related quality of life, PedsQL, children, parents, preschool age.

\section{Introduction}

Health-related quality of life (HRQOL) focuses on the physical, psychological and social aspects of child health and allows outlining the peculiarities of daily functioning, the difficulties in performing daily activities, including those that are critical to well-being (Bowling, 2005; Prystupa \& Pavlova, 2015; Veenhoven, 2000). In fact, the analysis of HRQOL includes the subjective assessment of own health, existing acute/chronic diseases, positive/negative effects of treatment on the physical, mental and social functioning of the individual (Pavlova, 2015). Despite the fact that such approaches can be used to study the quality of life of people of all ages, in the case of working with children, there are certain features (Eiser, 1997; Ravens-Sieberer, Karow, Barthel, \& Klasen, 2014). This is due to the fact that it is rather difficult to assess the positive/negative effects of various factors in this age period, as they themselves can be part of development and maturation. However, in general, information about all indicators of quality of life should be organically interwoven with the content of questions, and the method of research should take into account the child's ability to communicate, express and understand feelings, questions, use the time concepts (for example, during the last week, month, etc.).

An analysis of children's life quality allows answering a number of questions related to their emotional states, social relations, medical interventions and rehabilitation to better understand the problems in the child development and the difficulties that arise when communicating with parents and peers, to assess cognitive and gaming activities, behaviour, own self-perception, to analyse crucial factors that affect the health of the child (bad sleep, the presence of pain, bullying, unfavourable environment, etc.). The tools used to assess the quality of life of children are multidimensional, so they allow for such a comprehensive assessment (Eiser \& Morse, 2001). Usually, they have a common module/modules with questions and, additionally, there may be separate question blocks focused on the study of a particular disease (Varni, Seid, \& Rode, 1999; Varni, Limbers, \& Burwinkle, 2007). The universal module allows to calculate the quality of life of a healthy population, and special modules contain unique questions focusing on certain chronic diseases and more precisely characterise the effect of disease on the health and daily activity of respondents (Bowling, 2005; Eiser, 1997; Upton, Lawford, \& Eiser, 2008). Most of the methods are designed for children older than 5 years; moreover, parents and guardians of the child are involved in the survey.

According to the vision of the World Health Organization, children should have access to health information and should be visible to policymakers, decision-makers and assistants. Understanding the quality of life of a child by calculating the HRQOL in quantitative equivalent, is important for assessing the impact of diseases on various aspects of well-being and predicting the health status of the population in the future. 
The purpose of the study was to analyse the differences in the physical, psychological and social components of the quality of life of the child of preschool age by the responses of children and parents.

\section{Material and Methods}

The survey was attended by 57 children (passport age -5 years) and their parents. Adult subjects signed an agreement for participation in the study.

The Pediatric Quality of Life Inventory (PedsQL ${ }^{\mathrm{TM}}$ 4.0) was used to assess the quality of life (Varni et al., 1999; Varni et al., 2007). In order to apply the Generic Core Scales, a User Agreement was signed with the Mapi Research Trust (Lyon, France) and received special permission to conduct the survey and the Ukrainian version of the questionnaire.

The study used a version of the questionnaire for children and parents. The questionnaire consists of separate units, and the total number of questions is 23 . The results of the survey were calculated according to the 4 scales Physical Functioning (8 questions), Emotional Functioning (5 questions), Social Functioning (5 questions), Kindergarten Functioning ( 5 questions). To assess children's responses, a scale with three options was used. For each question, the child was asked to indicate the emotional state of the corresponding icon ("Not a problem at all" - smiling face, "Sometimes a problem" - middle face, "A problem a lot" - frowning face). Parents' opinions were evaluated using a scale with 5 variants of response ("Never", "Almost never", "Sometimes", "Often", "Almost always").

The values of quality of life for each parameter were counted on a 100-point scale. If more than $50 \%$ of the questions of a separate block were omitted, then the final indicator for this parameter was not calculated. The higher the score indicated the better the quality of life of the respondent. Values below 50 points were interpreted as poor quality of life, 51-75 points - average, above 75 points - high.

Origin Pro 8.6 was used for statistical processing of data. The average (M), the corrected mean square deviation (SD), standard error (SE), the smallest value $\left(X_{\min }\right)$, the highest value $\left(X_{\max }\right)$ and the median $(\mathrm{Me})$ were determined. Differences between groups were determined using the Kruskal-Wallis ANOVA, and the probability was set at $\mathrm{p}<.05$.

\section{Results}

The quality of life of children on most scales was in high range (Table 1). For most scales, the indicators exceeded 75 points (Physical Functioning $-78.7 \pm 1.9$ points, Emotional Functioning $-82.3 \pm 2.6$ points, Social Functioning $-76.1 \pm 2.8$ points), and only on the Kindergarten Functioning scale, the quality of life was in the middle range $(73.9 \pm 3.0$ points). The assessment of the quality of life of the child by parents was significantly lower and statistically significantly different in the Physical Functioning (by 10.9 points), Emotional Functioning (by 12.7 points) and Kindergarten Functioning (by 9.2 points) scales.

Table 1. Comparison of the quality of life of children by self-assessment and proxy surveys

\begin{tabular}{|c|c|c|c|c|c|c|c|c|c|}
\hline \multirow{2}{*}{$\begin{array}{l}\text { Group of } \\
\text { respondents }\end{array}$} & \multirow[b]{2}{*}{$\mathrm{N}$} & \multicolumn{6}{|c|}{ Quality of life, points } & \multirow{2}{*}{$\mathrm{Z}$} & \multirow[b]{2}{*}{$\mathrm{p}$} \\
\hline & & $\mathrm{M} \pm \mathrm{SE}$ & SD & $95 \% \mathrm{CI}$ & $\mathrm{X}_{\min }$ & $\mathrm{Me}$ & $\mathrm{X}_{\max }$ & & \\
\hline \multicolumn{10}{|c|}{ Physical Functioning } \\
\hline Children & \multirow{2}{*}{52} & $78.7 \pm 1.9$ & 14.0 & $75.0 ; 82.4$ & 43.8 & 75.0 & 100.0 & 3.41 & $<.001$ \\
\hline Parents & & $67.8 \pm 2.5$ & 18.4 & $62.7 ; 72.9$ & 28.1 & 70.3 & 100.0 & & \\
\hline \multicolumn{10}{|c|}{ Emotional Functioning } \\
\hline Children & \multirow{2}{*}{52} & $82.3 \pm 2.6$ & 19.7 & $77.0 ; 87.5$ & 0.0 & 90.0 & 100.0 & 4.47 & $<.001$ \\
\hline Parents & & $69.6 \pm 1.8$ & 12.7 & $66.1 ; 73.2$ & 50.0 & 70.0 & 100.0 & & \\
\hline \multicolumn{10}{|c|}{ Social Functioning } \\
\hline Children & \multirow{2}{*}{54} & $76.1 \pm 2.8$ & 21.2 & $70.5 ; 81.8$ & 20.0 & 80.0 & 100.0 & .65 & .52 \\
\hline Parents & & $74.4 \pm 2.0$ & 14.4 & $70.5 ; 78.4$ & 40.0 & 75.0 & 100.0 & & \\
\hline \multicolumn{10}{|c|}{ Kindergarten Functioning } \\
\hline Children & \multirow{2}{*}{54} & $73.9 \pm 3.0$ & 22.7 & $67.8 ; 79.9$ & 20.0 & 80.0 & 100.0 & 2.31 & .02 \\
\hline Parents & & $64.7 \pm 2.0$ & 14.6 & $60.7 ; 68.7$ & 30.0 & 65.0 & 95.0 & & \\
\hline
\end{tabular}


A detailed analysis of the subjects' responses found that children evaluated better their own physical abilities, were be able to cope with everyday tasks and seldom had a low level of energy or pain complaint (Table 2). Among this group of respondents, $93.0 \%$ stated that they did not have problems with walking, $89.5 \%$ - with running, 75.4\% - with self-service (taking a bath or shower) and fulfilling the orders of parents, and $86.0 \%$ felt energetic. The results of the proxy survey were significantly different. Parents gave a more critical assessment of various aspects of the physical functioning of the child. So, only $64.9 \%$ said that the child had no problems with long-distance travel, half of parents confirmed that the child needed self-care assistance, and only $19.3 \%$ were convinced that the child was able to carry out house-specific tasks without any problems. A significant proportion of parents noticed that children needed help in lifting heavy things, and $47.3 \%$ of children almost never had pain feelings. The opinion of parents and children about physical education and/or sports was practically similar - this activity was not at all a problem for $56.1 \%$ and $59.6 \%$, respectively, but the result of self-assessment and proxy evaluation showed that sometimes there was a problem - for $22.8 \%$ of children, regardless of the group of respondents.

Table 2. Health and activity of children by self-assessment and proxy evaluation

\begin{tabular}{|c|c|c|c|c|c|c|c|}
\hline & \multirow{3}{*}{$\begin{array}{l}\text { Group of } \\
\text { respondents }\end{array}$} & \multicolumn{6}{|c|}{ Relative number of respondents, $\%$} \\
\hline & & \multicolumn{2}{|c|}{ Not a problem at all } & \multirow{2}{*}{$\begin{array}{l}\text { Sometimes } \\
\text { a problem }\end{array}$} & \multicolumn{2}{|c|}{ A problem a lot } & \multirow{2}{*}{$\begin{array}{l}\text { No } \\
\text { response }\end{array}$} \\
\hline & & Never & $\begin{array}{l}\text { Almost } \\
\text { never }\end{array}$ & & Often & $\begin{array}{l}\text { Almost } \\
\text { always }\end{array}$ & \\
\hline \multirow[t]{2}{*}{ Problems with walking } & Children & \multicolumn{2}{|c|}{93.0} & 1.8 & \multicolumn{2}{|c|}{5.3} & - \\
\hline & Parents & 47.4 & 17.5 & 12.3 & 12.3 & 7.0 & 3.5 \\
\hline \multirow[t]{2}{*}{ Problems with jogging } & Children & \multicolumn{2}{|c|}{89.5} & 3.5 & \multicolumn{2}{|c|}{7.0} & - \\
\hline & Parents & 54.4 & 22.8 & 10.5 & 8.8 & 1.8 & 1.8 \\
\hline Problems with & Children & \multicolumn{2}{|c|}{56.1} & 22.8 & \multicolumn{2}{|c|}{21.1} & - \\
\hline $\begin{array}{l}\text { participating in sports } \\
\text { activity or exercise }\end{array}$ & Parents & 36.8 & 22.8 & 22.8 & 10.5 & 1.8 & 5.3 \\
\hline \multirow{2}{*}{$\begin{array}{l}\text { Problems with lifting } \\
\text { heavy things }\end{array}$} & Children & \multicolumn{2}{|c|}{33.3} & 5.3 & \multicolumn{2}{|c|}{61.4} & - \\
\hline & Parents & 31.6 & 33.3 & 26.3 & 7.0 & 1.8 & - \\
\hline \multirow{2}{*}{$\begin{array}{l}\text { Problems with taking a } \\
\text { bath or shower }\end{array}$} & Children & \multicolumn{2}{|c|}{75.4} & 8.8 & \multicolumn{2}{|c|}{14.0} & - \\
\hline & Parents & 36.8 & 14.0 & 24.6 & 12.3 & 10.5 & 1.8 \\
\hline \multirow{2}{*}{$\begin{array}{l}\text { Problems with doing } \\
\text { chores (like picking up } \\
\text { toys) }\end{array}$} & Children & \multicolumn{2}{|c|}{75.4} & 8.8 & \multicolumn{2}{|c|}{15.8} & - \\
\hline & Parents & 12.3 & 7.0 & 42.1 & 28.1 & 8.8 & 1.8 \\
\hline \multirow[t]{2}{*}{ Complaints about pain } & Children & \multicolumn{2}{|c|}{89.5} & 7.0 & \multicolumn{2}{|c|}{3.5} & - \\
\hline & Parents & 14.0 & 33.3 & 35.1 & 10.5 & 5.3 & 1.8 \\
\hline \multirow[t]{2}{*}{ Low-energy level } & Children & \multirow{2}{*}{\multicolumn{2}{|c|}{404}} & 5.3 & \multicolumn{2}{|c|}{8.8} & - \\
\hline & Parents & & & 21.1 & 3.5 & 1.8 & 3.5 \\
\hline
\end{tabular}

Distinctions in the assessment of the emotional state of the child according to the responses of different groups of participants were revealed. Most children (73.7-77.2\%) indicated they did not feel fear, sadness, or worries about the future (Table 3). Only $33.4 \%$ of parents claimed that the child did not feel fear, $52.6 \%$ - was not sad, $42.1 \%$ - was not angry. However, parents better evaluated the quality of a child's sleep; $57.9 \%$ of children noted they had no sleep problems, while among parents, this response scored $77.2 \%$. Unlike the Physical Functioning scale, where a significant number of parents noticed significant difficulties $(19.7 \%$ had problems with shortdistance walking, $10.6 \%$ - with running, $12.3 \%$ - during physical education/sports, $22.8 \%$ - had difficulties with self-service, $15.8 \%$ - pain complaints), the respondents generally evaluated the emotional state positively. Bad mood and unsatisfactory emotional state significantly impeded $1.8-8.8 \%$ of respondents.

Despite the fact that the overall score for the quality of life on the Social Functioning scale, according to selfassessment and proxy evaluation, was not statistically significantly different (see Table 1), responses to individual questions varied significantly (Table 4). Young respondents stated that they were easily friends with their peers $(91.2 \%)$, were not teased (75.4\%) and, during the games, did not lag behind others (71.9\%). 
Moreover, the establishment of a common language with peers, comparing own achievements to those of other children, would be among concerns. Up to $18 \%$ of children considered that they were lagging behind when interacting with others, were not able to do certain things that their peers could, or other children did not want to play with them.

Less than half of parents were convinced that children could easily concentrate on classes in kindergarten (42.1\%), did not forget things $(49.2 \%)$, easily fulfilled tasks of the educator $(47.4 \%)$, or did not miss classes because of health problems (45.6-66.7\%). Instead, according to the responses of children, $70.2 \%$ focused easily on the tasks they performed. The main problems can be considered missing kindergarten because of poor health $(29.8 \%)$ and visits to the doctor $(31.6 \%)$.

Table 3. Assessment of the emotional state of children by self-assessment and proxy evaluation

\begin{tabular}{|c|c|c|c|c|c|c|c|}
\hline & \multirow{3}{*}{$\begin{array}{l}\text { Group of } \\
\text { respondents }\end{array}$} & \multicolumn{6}{|c|}{ Relative number of respondents, $\%$} \\
\hline & & \multicolumn{2}{|c|}{ Not a problem at all } & \multirow{2}{*}{$\begin{array}{l}\text { Sometimes } \\
\text { a problem }\end{array}$} & \multicolumn{2}{|c|}{ A problem a lot } & \multirow{2}{*}{$\begin{array}{c}\text { No } \\
\text { response }\end{array}$} \\
\hline & & Never & $\begin{array}{l}\text { Almost } \\
\text { never }\end{array}$ & & Often & $\begin{array}{l}\text { lmost } \\
\text { lways }\end{array}$ & \\
\hline \multirow[t]{2}{*}{ Feeling of fear } & Children & \multicolumn{2}{|c|}{77.2} & 15.8 & \multicolumn{2}{|c|}{7.0} & - \\
\hline & Parents & 8.8 & 24.6 & 57.9 & 8.8 & - & - \\
\hline \multirow[t]{2}{*}{ Feeling of sadness } & Children & \multicolumn{2}{|c|}{75.4} & 19.3 & \multicolumn{2}{|c|}{5.3} & - \\
\hline & Parents & 10.5 & 42.1 & 42.1 & 1.8 & - & 3.5 \\
\hline \multirow[t]{2}{*}{ Feeling of anger } & Children & \multicolumn{2}{|c|}{75.4} & 17.5 & \multicolumn{2}{|c|}{7.0} & - \\
\hline & Parents & 15.8 & 26.3 & 43.9 & 8.8 & - & 5.3 \\
\hline \multirow[t]{2}{*}{ Trouble with sleeping } & Children & \multicolumn{2}{|c|}{57.9} & 33.3 & \multicolumn{2}{|c|}{8.8} & - \\
\hline & Parents & 36.8 & 40.4 & 19.3 & 1.8 & - & 1.8 \\
\hline \multirow{2}{*}{$\begin{array}{l}\text { Worrying about what } \\
\text { will happen }\end{array}$} & Children & \multicolumn{2}{|c|}{73.7} & 17.5 & \multicolumn{2}{|c|}{7.0} & \\
\hline & Parents & 36.8 & 29.8 & 26.3 & - & - & 7.0 \\
\hline
\end{tabular}

Table 4. Assessment of children's relationships by self-assessment and proxy evaluation

\begin{tabular}{|c|c|c|c|c|c|c|c|}
\hline & \multirow{3}{*}{$\begin{array}{l}\text { Group of } \\
\text { respondents }\end{array}$} & \multicolumn{6}{|c|}{ Relative number of respondents, $\%$} \\
\hline & & \multicolumn{2}{|c|}{ Not a problem at all } & \multirow{2}{*}{$\begin{array}{c}\text { Sometimes } \\
\text { a problem }\end{array}$} & \multicolumn{2}{|c|}{ A problem a lot } & \multirow{2}{*}{$\begin{array}{c}\text { No } \\
\text { response }\end{array}$} \\
\hline & & Never & $\begin{array}{l}\text { Almost } \\
\text { never }\end{array}$ & & Often & $\begin{array}{l}\text { Almost } \\
\text { always }\end{array}$ & \\
\hline \multicolumn{8}{|c|}{ Social Functioning } \\
\hline Getting along with other & Children & \multicolumn{2}{|c|}{91.2} & 5.3 & \multicolumn{2}{|c|}{3.5} & - \\
\hline children & Parents & 26.3 & 33.3 & 19.3 & 10.5 & 10.5 & - \\
\hline Other children not wanting & Children & \multicolumn{2}{|c|}{40.4} & 42.1 & \multicolumn{2}{|c|}{17.5} & - \\
\hline to be the child's friend & Parents & 35.1 & 38.6 & 21.1 & 1.8 & 1.8 & 1.8 \\
\hline Getting teased by other & Children & \multicolumn{2}{|c|}{75.4} & 15.8 & \multicolumn{2}{|c|}{8.8} & - \\
\hline children & Parents & 31.6 & 50.9 & 15.8 & - & - & 1.8 \\
\hline Inability to do what peers & Children & \multicolumn{2}{|c|}{59.6} & 22.8 & \multicolumn{2}{|c|}{17.5} & - \\
\hline do & Parents & 21.1 & 49.1 & 26.3 & 1.8 & - & 1.8 \\
\hline Keeping up playing with & Children & \multicolumn{2}{|c|}{71.9} & 14.0 & \multicolumn{2}{|c|}{14.0} & - \\
\hline other children & Parents & 38.6 & 38.6 & 17.5 & - & - & 5.3 \\
\hline \multicolumn{8}{|c|}{ Kindergarten Functioning } \\
\hline Paying attention during & Children & \multicolumn{2}{|c|}{70.2} & 17.5 & \multicolumn{2}{|c|}{12.3} & - \\
\hline the class & Parents & 19.3 & 22.8 & 35.1 & 12.3 & 7.0 & 3.5 \\
\hline \multirow[t]{2}{*}{ Forgetting things } & Children & \multicolumn{2}{|c|}{56.1} & 24.6 & \multicolumn{2}{|c|}{19.3} & - \\
\hline & Parents & 21.1 & 28.1 & 43.9 & 5.3 & - & 1.8 \\
\hline Keeping up with & Children & \multicolumn{2}{|c|}{71.9} & 15.8 & \multicolumn{2}{|c|}{12.3} & - \\
\hline kindergarten activities & Parents & 24.6 & 22.8 & 35.1 & 8.8 & 7.0 & 1.8 \\
\hline Missing kindergarten & Children & \multicolumn{2}{|c|}{56.1} & 14.0 & \multicolumn{2}{|c|}{29.8} & - \\
\hline
\end{tabular}


International Proceedings of Human Motricity/ ICPESK 2019

Supplementary Issue of Discobolul - Physical Education, Sport and Kinetotherapy Journal, 2019

\begin{tabular}{llcccccc} 
because of not feeling well & Parents & 10.5 & 35.1 & 42.1 & 8.8 & - & 3.5 \\
\hline $\begin{array}{l}\text { Missing kindergarten to go } \\
\text { to the doctor or hospital }\end{array}$ & Children & \multicolumn{2}{c}{59.6} & 8.8 & & 31.6 & - \\
\hline
\end{tabular}

\section{Discussion}

The issues of quality of life are the subject of discussion in various fields of science. On the basis of the life quality concept, there are several key ideas: first, individuals have their own vision of quality of life, which depends on lifestyle, past events, prospects of the future, dreams and expectations; second, even in the medical context, quality of life remains a multi-component construction, and the analysis is not limited to the statement of the absence of the disease; third, quality of life can be assessed from an objective or subjective point of view (Eiser \& Morse, 2001). According to the objective approach, the attention of the researcher focuses on human capabilities, so it is important to determine the level of health of an individual (Prystupa \& Pavlova, 2015). The subjective evaluation includes the values for the individual. The presence of these two approaches explains the fact that people with the same health level can report a different quality of life.

Despite the fact that most developers of evaluation techniques interpret the quality of life as a multidimensional construct, most often they analyse components related to the physical, social and emotional existence of humans, while other aspects of life (e.g., the cognitive or spiritual ones) are considered much less frequently (Pavlova, Vynogradskyi, Ripak, Zikrach, \& Borek, 2016; Prystupa \& Pavlova, 2015; Varni et al., 1999). However, the essence of these domains varies considerably depending on the needs and requirements of society, cultural characteristics, etc. In this regard, the quality of life of Ukrainian children remains practically unexplored.

Evaluating the quality of life of children is associated with a number of difficulties, so parents/guardians must be involved in the assessment of the well-being of children under the age of 8 years (Pickard \& Knight, 2005; Upton et al., 2008). However, children and parents do not necessarily have common views on daily activities; children may not share parents' opinions about the causes, course and treatment of the disease. Children, due to cognitive, speech and age development, can interpret the question differently, understand time in a different way, not understand the scale of evaluation or language constructs, etc. (Eiser, 1997; Upton et al., 2008)

The point when assessing the quality of life of children remains consideration of their level of development, natural changes that occur over time. Comparing the thoughts of children and parents answers the question whether the mental state of parents, their perception of the child's activity and level of health can affect family relationships, the quality of life of the child in the future.

Among the issues that remain open to the study of the quality of life of children, we mention: (1) the use of common research tools that have additional modules for the analysis of a disease; (2) the development of research tools that can be used directly by children (Davis et al., 2007; Eiser, 1997; Ravens-Sieberer et al., 2014; Varni et al., 1999).

The PedsQL method used in the study receives promising feedback from researchers around the world and provides reliable and valid results (Upton et al., 2008; Varni et al., 1999; Varni et al., 2007; Viira \& Koka, 2011). The overall quality-of-life indicator is influenced by various factors. The main ones, according to scientists, are medical (the presence of chronic diseases, their duration and symptoms) and socio-demographic factors (Arabiat, Elliott, Draper, \& Al Jabery, 2011; Bergier et al., 2018; Brodani \& Kovacova, 2019; Pacesova, Smela, \& Kracek, 2019; Pavlova, Vynogradskyi, Borek, \& Borek, 2015; Pavlova, Vynogradskyi, Kurchaba, \& Zikrach, 2017; Pavlova, Stefankiv, \& Vynogradskyi, 2016). So, in the presence of chronic diseases, the younger the respondent, the lower their quality of life (Varni et al., 2007).

The highest rates of quality of life are usually on the Physical Functioning scale (Ji et al., 2011; Klatchoian et al., 2008; Petersen, Hägglöf, Stenlund, \& Bergström, 2009; Raj et al., 2017; Varni et al., 2007; Viira \& Koka, 2011). Most studies have shown that the quality-of-life indicators on the Emotional Functioning scale are the lowest, which differs from the results received for Ukrainian children. Despite the fact that the quality of life of Ukrainian preschool children can be interpreted as high, all indicators are significantly lower, compared with the data of other countries of the world. In general, the quality of life of Ukrainian children, on all scales, was lower than that of citizens of the USA (Varni et al., 2007), Brazil (Klatchoian et al., 2008), Sweden (Petersen et al., 2009), Estonia (Viira \& Koka, 2011), India (Raj et al., 2017), China (Ji et al., 2011). For example, the overall quality of life of younger children living in India was $90.4 \pm 8.1$ points, and the scales were in the range of 80.396.4 points (Raj et al., 2017). In children of the same age group from Brazil, the quality of life was $88.9 \pm 7.4$ 
points (Klatchoian et al., 2008). The indexes we received for Ukrainian children are close to the quality of life of healthy respondents who studied in Jordanian schools or were in Palestinian refugee camps (79.0 \pm 14.8 points, range of values according to the scale - 73.6-81.1 points) (Arabiat et al., 2011).

According to the results of our study, in general, parents gave a lower assessment of the quality of life of the child. Significant differences were found on the scale characterising the physical functioning and emotional state of the child, instead of a different assessment of social functioning. Some studies (Davis et al., 2007; Upton et al., 2008) revealed weak and strong correlations between the estimates of parents and children; there were generally no differences in the assessment of physical well-being, and weak correlations were noted according to unobserved aspects of the quality of life - emotional well-being. It is believed that, in children older than 8 years, parents' ratings can only supplement the child's self-report, but do not replace it (Upton et al., 2008). Parents cannot be regarded as absolutely objective judges, but they have their own points of view, which can serve as an additional source of information.

Despite the discrepancy between the assessment given by the child and the assessment based on the results of parents' responses, consideration of the child's views is of great importance. Parents' opinions are influenced by the level of development of other children, their personal expectations and expectations regarding the child, concerns about the health of the child, additional life circumstances and their own mental state. The assessment of parents is more critical: it can reflect the level of development of the child, his/her ability according to age development, and this pattern can be clearly seen in relation to the physical functioning of the child (differences in the responses to the questions about lifting heavy things, walking a long distance, doing homework). Exceptions can be considered issues relating to the level of physical fitness, physical education/sports, absenteeism due to illness - the opinion of children and parents on these issues was similar. It is also necessary to note the significant differences in the assessment of social functioning of the child. In general, parents' responses, in this case, can be considered as more optimistic. If $17.5 \%$ of children had a problem with their peers to feel equal with them, $8.8 \%$ said they were teased by others, and $3.6 \%$ of parents had the same opinion.

\section{Conclusion}

The quality of life of Ukrainian preschool children is in a high range, but is lower in comparison with healthy respondents of the same age group from other countries. Critical for the low-value scales (Social Functioning, Kindergarten Functioning) identified problems with peers (lack of communication, bullying). Parents give a more critical assessment of various aspects of the physical, emotional and social functioning of the child and are a source of additional information about the quality of life of the child.

\section{References}

Arabiat, D., Elliott, B., Draper, P., \& Al Jabery, M. (2011). Cross-cultural validation of the Pediatric Quality of Life Inventory ${ }^{\mathrm{TM}} 4.0$ (PedsQL ${ }^{\mathrm{TM}}$ ) Generic Core Scale into Arabic language. Scandinavian Journal of Caring Sciences, 25(4), 828-833. https://doi.org/10.1111/j.1471-6712.2011.00889.x

Bergier, J., Tsos, A., Popovych, D., Bergier, B., Niźnikowska, E., Ács, P., ... Salonna, F. (2018). Level of and factors determining physical activity in students in Ukraine and the Visegrad countries. International Journal of Environmental Research and Public Health, 15(8): 1738. https://doi.org/10.3390/ijerph15081738

Bowling, A. (2005). Measuring health: A review of quality of life measurement scales. Open University Press.

Brodani, J., \& Kovacova, N. (2019). The interaction of physical activity, joy of movement and quality of life of high school students at different ages. Physical Activity Review, 7, 134-142. doi: 10.16926/par.2019.07.16

Davis, E., Nicolas, C., Waters, E., Cook, K., Gibbs, L., Gosch, A., \& Ravens-Sieberer, U. (2007). Parent-proxy and child self-reported health-related quality of life: Using qualitative methods to explain the discordance. Quality of Life Research, 16(5), 863-871. https://doi.org/10.1007/s11136-007-9187-3

Eiser, C. (1997). Children's quality of life measures. Archives of Disease in Childhood, 77(4), 350-354. https://dx.doi.org/10.1136\%2Fadc.77.4.350

Eiser, C., \& Morse, R. (2001). A review of measures of quality of life for children with chronic illness. Archives of Disease in Childhood, 84(3), 205-211. https://dx.doi.org/10.1136\%2Fadc.84.3.205

Ji, Y., Chen, S., Li, K., Xiao, N., Yang, X., Zheng, S., \& Xiao, X. (2011). Measuring health-related quality of life in children with cancer living in mainland China: Feasibility, reliability and validity of the Chinese mandarin version of PedsQL 4.0 Generic Core Scales and 3.0 Cancer Module. Health and Quality of Life Outcomes, 
9(1): 103. https://doi.org/10.1186/1477-7525-9-103

Klatchoian, D. A., Len, C. A., Terreri, M. T. R. A., Silva, M., Itamoto, C., Ciconelli, R. M., ... Hilário, M. O. E. (2008). Qualidade de vida de crianças e adolescentes de São Paulo: Confiabilidade e validade da versão brasileira do questionário genérico Pediatric Quality of Life Inventory ${ }^{\mathrm{TM}}$ versão 4.0. [Quality of life of children and adolescents from São Paulo: Reliability and validity of the Brazilian version of the Pediatric Quality of Life Inventory ${ }^{\mathrm{TM}}$ version 4.0.]. Jornal de Pediatria, 84(4), 308-315. http://dx.doi.org/10.1590/S002175572008000400005

Pacesova, P., Smela, P., \& Kracek, S. (2019). Personal well-being as part of the quality of life: Is there a difference in the personal well-being of women and men with higher level of anxiety trait regarding their sport activity? Physical Activity Review, 7, 201-208. doi: 10.16926/par.2019.07.24

Pavlova, I. (2015). The structure of population life quality. Slobozans kij naukovo-sportivnij visnik, 5(49), 90-94. doi:10.15391/snsv.2015-5.015

Pavlova, I., Stefankiv, M., \& Vynogradskyi, B. (2016). Professional level and life quality of physical culture and basics of health teachers of primary school. The European Proceedings of Social \& Behavioural Sciences, IX, 113-120. https://doi.org/10.15405/epsbs.2016.06.16

Pavlova, I., Vynogradskyi, B., Borek, Z., \& Borek, I. (2015). Life quality and physical activity of Ukrainian residents. Journal of Physical Education and Sport, 15(4), 809-814. doi: 10.7752/jpes.2015.04124

Pavlova, I., Vynogradskyi, B., Kurchaba, T., \& Zikrach, D. (2017). Influence of leisure-time physical activity on quality of life of Ukrainian students. Journal of Physical Education and Sport, 17(3), 1037-1042. doi: 10.7752/jpes.2017.03159

Pavlova, I., Vynogradskyi, B., Ripak, I., Zikrach, D., \& Borek, Z. (2016). Prognostication of health-related life quality of Ukrainian residents due to physical activity level. Journal of Physical Education and Sport, 16(2), 418-423. doi: 10.7752/jpes.2016.02065

Petersen, S., Hägglöf, B., Stenlund, H., \& Bergström, E. (2009). Psychometric properties of the Swedish PedsQL, Pediatric Quality of Life Inventory 4.0 Generic Core Scales. Acta Paediatrica, 98(9), 1504-1512. https://doi.org/10.1111/j.1651-2227.2009.01360.x

Pickard, A. S., \& Knight, S. J. (2005). Proxy evaluation of health-related quality of life: A conceptual framework for understanding multiple proxy perspectives. Medical Care, 43(5), 493-499. Retrieved from https://www.ncbi.nlm.nih.gov/pmc/articles/PMC1188232/

Prystupa, E., \& Pavlova, I. (2015). Evaluation of health in context of life quality studying. Postepy Rehabilitacji, 29(2), 33-38. https://doi.org/10.1515/rehab-2015-0025

Raj, M., Sudhakar, A., Roy, R., Champaneri, B., Joy, T. M., \& Kumar, R. K. (2017). Health-related quality of life in Indian children: A community-based cross-sectional survey. The Indian Journal of Medical Research, 145(4): 521. https://doi.org/10.4103/ijmr.IJMR_447_16

Ravens-Sieberer, U., Karow, A., Barthel, D., \& Klasen, F. (2014). How to assess quality of life in child and adolescent psychiatry. Dialogues in Clinical Neuroscience, 16(2), 147-158. Retrieved from https://www.ncbi.nlm.nih.gov/pmc/articles/PMC4140509/

Upton, P., Lawford, J., \& Eiser, C. (2008). Parent-child agreement across child health-related quality of life instruments: A review of the literature. Quality of Life Research, 17(6), 895-913. https://doi.org/10.1007/s11136-008-9350-5

Varni, J. W., Limbers, C. A., \& Burwinkle, T. M. (2007). Impaired health-related quality of life in children and adolescents with chronic conditions: A comparative analysis of 10 disease clusters and 33 disease categories/severities utilizing the PedsQL 4.0 Generic Core Scales. Health and Quality of Life Outcomes, 5: 43. https://doi.org/10.1186/1477-7525-5-43

Varni, J. W., Seid, M., \& Rode, C. A. (1999). The PedsQL: Measurement model for the pediatric quality of life inventory. Medical Care, 37(2), 126-139. https://psycnet.apa.org/doi/10.1097/00005650-199902000-00003

Veenhoven, R. (2000). The four qualities of life. Ordering concepts and measures of the good life. Journal of Happiness Studies, 1(1), 1-39. https://psycnet.apa.org/doi/10.1023/A:1010072010360

Viira, R., \& Koka, A. (2011). Health-related quality of life of Estonian adolescents: Reliability and validity of the PedsQL ${ }^{\mathrm{TM}}$ 4.0 Generic Core Scales in Estonia. Acta Paediatrica, 100(7), 1043-1047. http://dx.doi.org/10.1111/j.1651-2227.2011.02193.x 